\title{
Descriptions of perceived quality of life of residents from a quilombo in north Brazil
}

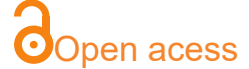

1Laboratório de Epidemiologia e análise de dados, Faculdade de Medicina do ABC (FMABC) - Santo André (SP), Brasil.

2Universidade Federal de Tocantins (UFT) - Palmas (TO), Brasil.

${ }^{3}$ Laboratório de Análises Clínicas da Faculdade de Medicina do ABC.

${ }^{4}$ Bolsa Produtividade em Pesquisa (CNPq no 309579 / 2015-5)

Corresponding author: luiz.sousa@fmabc.br

Manuscript received: January 2018 Manuscript accepted: March 2018 Version of record online: June 2018

\author{
Luiz Vinicius de Alcantara Sousa ${ }^{1}$, Erika da Silva Maciel $^{2}$, \\ Fernando Rodrigues Peixoto Quaresma ${ }^{1,2}$, Laércio da Silva \\ Paiva $^{1}$, Fernando Luiz Affonso Fonseca ${ }^{3}$, Fernando Adami ${ }^{1,4}$
}

\begin{abstract}
Introduction: The Quilombos inherently have the characteristic of resistance against the slave system, as their domination was linked to the idea of fugitive blacks and territorialization of free areas, they are usually an isolated community that tries to preserve the traditions, memories, and culture of its people.
\end{abstract}

Objetive: The study aimed to describe the perceptions regarding the quality of life of Quilombola community in the municipality of Santa Tereza, Tocantins, Brazil.

Methods: A descriptive cross-sectional study was conducted with children in the Quilombola community. To evaluate the children's quality of life, the questionnaire named Vie Enfant Imagé's Autoquestionnaire Qualité was used, composed of four factors: Autonomy, Leisure, Function, and Family. To evaluate the quality of life in adults, the World Health Organization Quality of Life assessment was used. The program used was Stata version 11.0.

Results: Regarding the quality of life of the children according to gender, the girls presented a mean of 11.0 in the Function factor, in the Family, Leisure, and Autonomy factor, presented with a mean of $12.3,8.2$ and 4.8 , respectively. For boys, the Function factor had a mean of 11.0, the Family factor of 12.0, and the Leisure and Autonomy factors of 7.6 and 5.6 , in this sequence. Among the adults, the men had lower values in the Physical domain with a mean of 13.7, the women had lower averages in the Physical and Environmental domains, with values equal to 13.8. In the general scores, the male sex obtained higher value when compared to the female sex, 14.0 and 13.6, respectively.

Conclusion: The study showed that among the children, the Family factor had higher mean values, followed by the Function, Leisure, and Autonomy factors, respectively. When studying adults, the domain with the best score was Social Relations, on the other hand, the Physical domain presented the worst score for men and women. However, investigations carried out regarding the quality of life in quilombolas represent a still low number, making it difficult to understand the possibilities of improving the quality of life in this population.

Keywords: quality of life, vulnerable populations, racial inequality, community. 


\section{INTRODUCTION}

The Quilombos inherently have the characteristic of resistance against the slave system, as their domination was linked to the idea of fugitive blacks and territorialization of free areas, they are usually an isolated community that tries to preserve the traditions, memories, and culture of its people $e^{1,2}$.

In Brazil, during the colonial period, Quilombos were characterized as any group of five fugitive blacks, regardless of their forms of habitation and survival, who settled in a certain region, living in the outskirts of the society that oppressed them with their concepts of slavery ${ }^{1,3}$.

Ethnic-racial populations with a considerable history of social exclusion, the Quilombolas gained greater recognition in Brazil when Article 68 of the Brazilian Constitution came into force in 1988, which became a historical landmark of Brazilian constitutionalism, recognizing the lands occupied by the communities ${ }^{2}$; in this sense, communities have grown, organized themselves, and are currently represented in most of the Brazilian states ${ }^{4}$.

\section{METHODS}

A cross-sectional descriptive study was conducted between October 2015 and September 2016 in the Quilombola community of Barra do Aroeira, located 12 kilometers from the urban area of Santa Teresa Municipality and 96 kilometers from Palmas, capital of the State of Tocantins. The community consists of descendants of slaves, the remaining Quilombolas duly recognized by the Palmares Cultural Foundation?.

For children, we used the questionnaire named Autoquestnaire Qualité de Vie Enfant Imagé (AUQEI), which has 26 items and a scale composed of four factors: Autonomy (items: 15, 17, 19, 23, and 24), Leisure (items: 11, 21, and 25), Function (items: 1, 2, 4, 5, and 8), and Family (items: 3, 10, 13, 16, and 18) covering 18 items; items $6,7,9,12,14,20,22$, and 26 were not included in the factors cited because they do not belong to a specific domain, and thus their analysis is separate from these factors ${ }^{10,11}$

Before administering the questionnaire, an image containing four emotional states (Figure 1) was presented to each child, so that they could be used as a basis for understanding their current emotional state ${ }^{10-12}$.
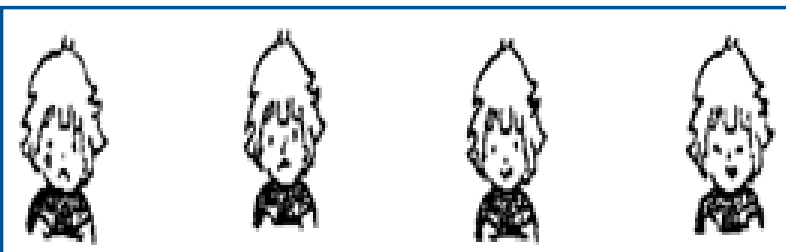

Figure 1: Faces of the AUQEI questionnaire.

After identifying the emotional state of the child, the items were read out to them, and they indicated their response, ranging from 0 to 3 (very unhappy, unhappy, happy, and very happy, respectively); a final score is calculated with the sum of scores on each question ${ }^{13}$.

Finally, the scores on all the questions were
Racial prejudices are still observed in the Brazilian population, making evident the losses in Quality of Life (QOL) and health care of the black population ${ }^{4,5}$. Thus, it is important to investigate the perceived QOL of the Quilombola community, considering that their way of life and organizational characteristics can directly influence this perception.

Measurement of QOL was evidenced based on the idea that the general description of health ceased to be just the absence of disease; therefore, in research, attention was directed to both welfare practices and public policies, since QOL is one of the main measures of impact on the public health of different populations ${ }^{6-8}$.

Quilombos they stayed away from the society, and could only benefit from the attention of government entities and health care policies later than others in the society, which promotes a strong influence on the QOL of Quilombolas. For these reasons, the purpose of this study was to describe the perception of the quality of life of Quilombolas in the Barra do Aroeira community in the municipality of Santa Tereza, Tocantins, Brazil.

summed, and the maximum score was 78 points; following the study of Assumpção Jr. et al. ${ }^{10}$, the cut-off value of 48 points was adopted to be considered a good QOL.

In order to assess the QOL in adults, the World Health Organization Quality of Life (WHOQOL-bref) was used, with 26 assertions divided into four domains: physical (items: 3, 4, 10, 15, 16, 17, and 18 ), psychological (items: 5, 6, 7, 11, 19, and 26), social relations (items: 20, 21, and 22), and environment (items: 8, 9, 12, 13, 14, 23, 24, and 25), in addition to 2 general assertions of QOL (items 1 and 2), which correspond to the 24 facets of the original WHOQOL (14), 2000 $0^{13-15}$.

Responses are recorded on a five-point Likert scale, which ranges from 1 to 5, based on the WHOQOL Group standards. The following measures were taken in addition

-We verified if all 26 questions were filled with values between 1 and 5 .

-We reverse scored all items whose scale of answers was reversed (items 3, 4, and 26).

-Domain scores were calculated by averaging the scores on the items in each domain. In domains composed of up to seven questions, the scores were not calculated if the number of unanswered items was two or more.

-In domains composed of more than seven items, the scores were not calculated if the number of unanswered items was three or more. The result was multiplied by four and represented on a scale of 4 to 20 .

-Respondents who failed to complete or incorrectly completed more than six questions $(80 \%$ of all instrument questions) were excluded from the sample. QOL ${ }^{13-16}$

The higher means suggest a better perception of

The researchers were trained to administer the questionnaires to avoid possible inconsistencies in data collection, although the instruments used in the study were composed of self-report items. The preparation of the data 
was carried out by two independent typists responsible for filling in duplicate in program Epi info and the third researcher was responsible for the validation of the data.

Descriptive analysis of qualitative data was performed using absolute frequency and relative frequency. For the quantitative variables, mean, standard deviation, range minimum and maximum values were used. The program used was Stata version 11.0.

\section{RESULTS}

The study sample consisted of 90 individuals, $25(27.8 \%)$ children and $65(72.2 \%)$ adults. Among the children, there were $13(52.0 \%)$ male participants with a mean age of 11.4 years and mean weight of $35.9 \mathrm{~kg}$. In adults, the sample consisted of $40(61.6 \%)$ women with a mean age of $31.0(19.4)$ years, with a mean weight of 60.9 $\mathrm{kg}$ (Table 1).

In the average scores, boys had higher values in
The present research was approved by the Research Ethics Committee of the Federal University of Tocantins, with protocol no. 2.003.276. At the beginning of data collection, the participants were guided about the steps of the study; in addition, they agreed to participate in the research by signing the Informed Consent Term (TCLE) and Informed Consent Term (TALE).

most items than girls (Figure 2).

Regarding the QOL of the children measured using the AUQEI and analyzed by factors, the female sex presented a mean of 11.0, 12.3, 8.2, and 4.8, in the Function, Family, Leisure, and Autonomy factors, respectively (Table 2). For boys, the means were 11.0, 12.0, 7.6, and 5.6 for Function, Family, Leisure, and Autonomy factors, respectively(Table 2).

Table 1: Characterization of children and adults living in the quilombola community Barra do Aroeira - TO, between 2015 and 2016.

\begin{tabular}{llcc}
\hline \multicolumn{1}{c}{ Children } & Male & $\mathbf{n}$ & $\%$ \\
sex & Female & 13 & 52.0 \\
& & 12 & 48.0 \\
Age (years) & Mean (sd) & Minimum - Maximum \\
Weight $(\mathrm{kg})$ & $11.4(1.1)$ & $10.0-13.0$ \\
Height $(\mathrm{cm})$ & $35.9(8.2)$ & $25.0-53.4$ \\
Adults & $144.5(9.4)$ & $127.9-163.3$ \\
Male & $\mathrm{n}$ & $\%$ \\
Female & 25 & 38.4 \\
Age years) & 40 & 61.6 \\
Weight $(\mathrm{kg})$ & Mean (sd) & $14.0-81.0$ \\
Height $(\mathrm{cm})$ & $31.0(19.4)$ & $39.8-113.0$ \\
Number of children & $60.9(15.9)$ & $141.0-180.0$ \\
\hline
\end{tabular}

sd: standard deviation.

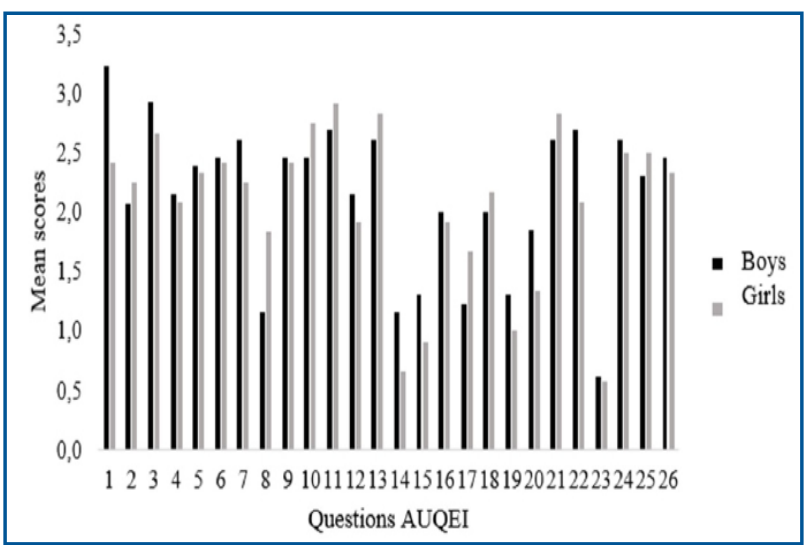

Figure 2: Average score of quilombola children by sex stratified according to the measurement of the instrument AUQEI.

Table 2: Mean scores of quilombola children divided by sex in relation to the four factors of the AUQEI.

\begin{tabular}{lcccc}
\hline Variables & \multicolumn{2}{c}{ Boys $(\mathbf{n = 1 3})$} & mean $(\mathrm{sd})$ & Girls $(\mathbf{n}=\mathbf{1 2})$ \\
\hline & mean $(\mathbf{s d})$ & minimum-maximum & $11.0(2.4)$ & $8.0-15.0$ \\
Function & $11.0(2.8)$ & $8.0-18.0$ & $12.3(1.8)$ & $9.0-14.0$ \\
Family & $12.0(3.1)$ & $7.0-19.0$ & $8.2(0.9)$ & $6.0-9.0$ \\
Leisure & $7.6(1.3)$ & $4.0-9.0$ & $4.8(1.8)$ & $2.0-9.0$ \\
Autonomy & $5.6(2.7)$ & $2.0-11.0$ & \\
\hline
\end{tabular}

sd: standard deviation. 
When observing the general scores, boys showed a higher average (55.6) than the girls (53.5) and the general score of the children was 54.6. When considering the classification suggested by Assumpção Jr. et al.10, who reported a favorable QOL in those with scores above 48 points, the study participants presented a positive perception of QOL (Figure 3).

The mean scores by items among adults were

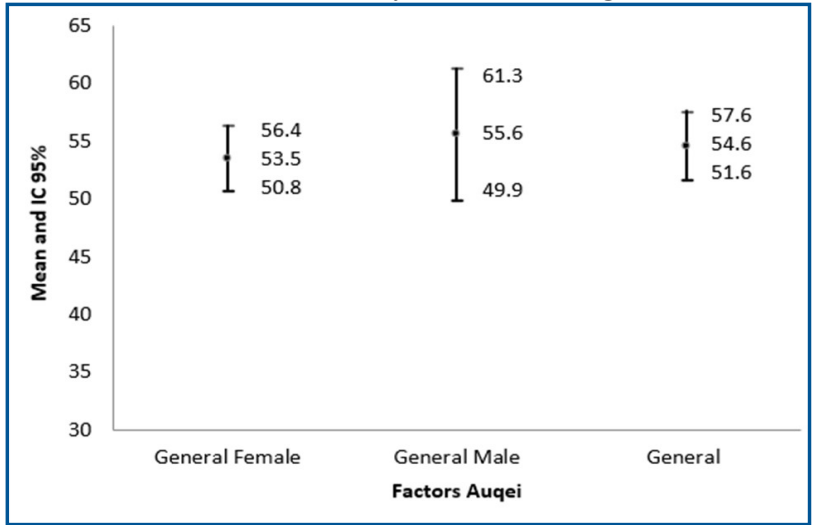

Figure 3: Presentation of the average score of the general quality of life level and divided by sex of the quilombola children. $95 \% \mathrm{Cl}$ : $95 \%$ confidence interval. approximate values, and male participants scored the highest on most items (Figure 4). Among adults, men had lower values in the Physical domain with a mean of 13.7, while women had lower averages in the Physical and Environmental domains, (values equal to 13.8) (Table 3).

In the general scores, the male sex obtained a value of 14.0, which was higher than that of female sex, which was 13.6 (Figure 5).

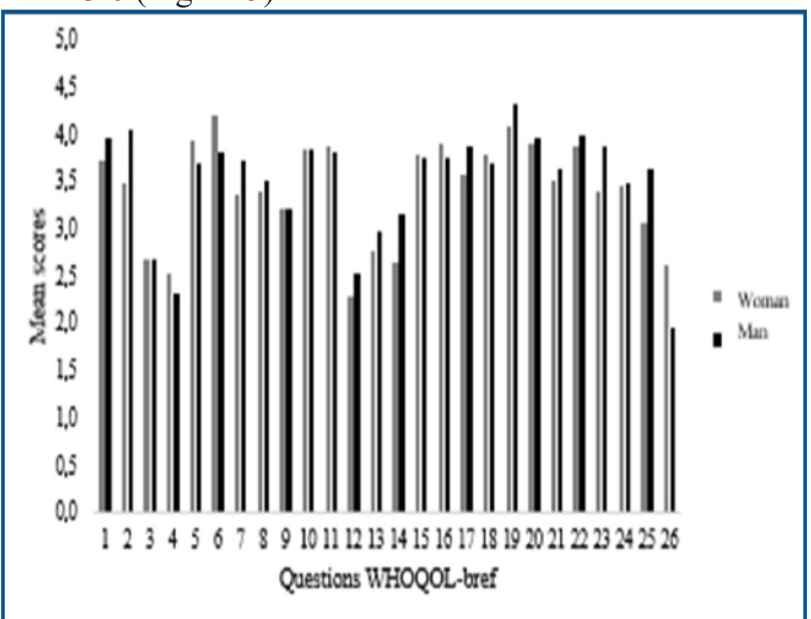

Figure 4: Mean scores of quilombola adults stratified by sex according to the measurement of the questionnaire WHOQOLbref.

Table 3: Quality of life of adolescents and adults stratified by gender measured by the instrument World Health Organization Quality of Life (WHOQOL-bref).

\begin{tabular}{lcccc}
\hline Variables & \multicolumn{2}{c}{ Male $(\mathbf{n = 2 5})$} & \multicolumn{2}{c}{ Female $(\mathbf{n = 4 0})$} \\
\hline Domains Whoqol & mean (sd) & minimum-maximum & mean (sd) & minimum-maximum \\
Physical & $13.7(1.7)$ & $8.0-16.0$ & $13.8(1.9)$ & $8.6-17.8$ \\
Psychological & $14.2(1.5)$ & $11.3-18.0$ & $14.7(1.6)$ & $10.8-18.0$ \\
Social Relations & $15.5(2.2)$ & $10.7-20.0$ & $15.1(3.1)$ & $4.0-20.0$ \\
Environment & $15.1(2.6)$ & $5.8-18.8$ & $13.8(2.7)$ & $6.8-20.0$ \\
\hline
\end{tabular}

sd: standard deviation.

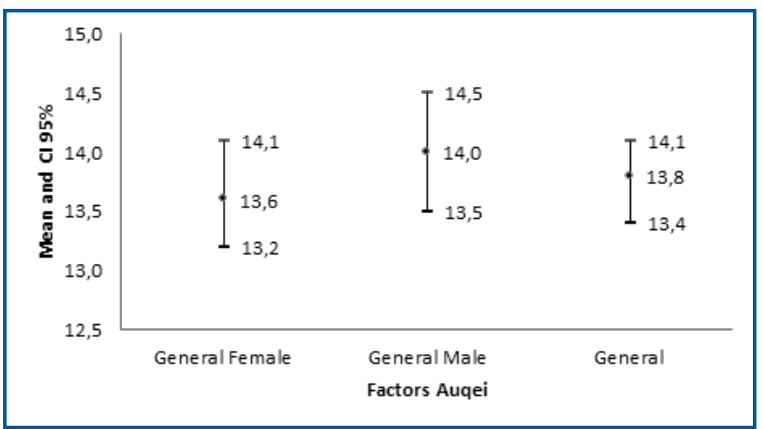

Figure 5: Presentation of the average score of the general quality of life level and divided by sex in quilombola adults. $95 \% \mathrm{Cl}$ : $95 \%$ confidence interval.

\section{DISCUSSION}

In the present study, it was possible to identify that the Family factor had a greater contribution in children's QOL, and the one with the worst perception was Autonomy, but the QOL is considered satisfactory because it is above the cut-off point as stipulated by Assumpção Jr. et al. ${ }^{10}$. In adults, the domain with the best score was Social Relations; on the other hand, the Physical domain had the worst score for men and women.
Among children, the general QOL score of the boys was higher than that of the girls, which is consistent with findings of Oliveira et al. ${ }^{12}$, who studied the QOL of 50 preschool children in one public school in 2014, where the boys showed a value of 65 points and the girls scored 47.6 points. This was also evidenced by the findings of Araújo et al. ${ }^{17}$, who evaluated a group of 36 individuals, among whom $84 \%$ women showed worse QOL scores. 
The lowest score in the domain of Autonomy in the present study can be explained by its composition, since the items indicate some dissatisfaction among children (such as playing alone, sleeping outside, when friends talk about you, being away, and receiving school grades).

Unlike the Autonomy domain, the Family domain obtained a higher average score; with the community having a predominance of rural subsistence, the family life has a larger influence, a result that can be noticed in items 3: "If you have siblings, when do you play with them?", 10: "When do you think about your father?", and 13: "When do you think of your mother?", which show higher scores and consequently, appreciation of the family.

In adults the scores found in the WHOQOLBref domains generally refer to QOL, which allows identification of the main demands of the population in focus, specifically aiming at the improvement or elaboration of public health policies ${ }^{18,19}$.

The physical domain among the adult population presented a lower value among the domains, which is consistent with previous results ${ }^{2,3}$, where, on analyzing a sample with 107 individuals from the city of Porto in the northern coast of Portugal, low scores were found in the physical domain.

The relationship between physical exercise and QOL was reported in other research ${ }^{20,21}$, which identified an association between leisure time physical activity and QOL related to health in 2,129 individuals aged 20-59 years. Thus, we can say that the low value in this domain found in the present research is associated with the influence of the responses related to "Pain and discomfort" and "Energy and fatigue," related to questions 3 and 4, respectively, on sleep and rest.

Andrade et $a l .{ }^{21}$ showed in their studies that low

\section{CONCLUSION}

The study showed that among the children, the Family factor had higher mean values, followed by the Function, Leisure, and Autonomy factors, respectively. When studying adults, the domain with the best score was Social Relations, on the other hand, the Physical domain presented the worst score for men and women. However, investigations carried out regarding the quality of life in quilombolas represent a still low number, making it difficult to understand the possibilities of improving the quality of life in this population.

\section{Compliance with Ethical Standards}

\section{Conflict of interests}

The authors declare that they have no conflicts of interest with respect to the authorship and/or publication of this article.

\section{Ethical approval}

Work in the communities began only after an agreement was reached on the Free and Informed Consent, which explained the research and respected the rights of privacy and autonomy of all participants. The present research obtained ethical appreciation (CAAE: 56954116.2.0000.5516). socioeconomic conditions promote a negative influence on QOL, showing no statistically significant association for sex, age, work, and income, but when analyzing QOL between genders, women were shown to have lower scores compared to men in almost all areas of the applied instrument.

The low income condition of a population is a good example when it comes to factors that promote negative changes in the QOL, and when it is associated with the ethnic factor, it promotes a worse evaluation of this perception, a condition that in Brazil can be justified by racial miscegenation and poor income distribution ${ }^{17}$.

According to Nishijima and Martins ${ }^{22}$, who studied the Quilombola community of Passo do Maia, located in Rio Grande do Sul, factors such as the migration of young people in search of work, low family income, and informal activities being the main sources, the educational level of the chiefs, benefits from social programs, importance of environmental preservation, and garbage collection, all promote a negative change in the perception of QOL of this population.

As Brazil is a large country, there are diverse cultures and various forms of distribution of public policies, in terms of the numerous Quilombola communities; the present study was thus limited to extrapolating data considering that QOL was measured in only one community with a relatively small population.

It is worth emphasizing that measuring the QOL level of the Quilombolas is essential due to its multidimensional character, but it is still difficult to be carried out due to the difficulties in accessing the communities and the structural obstacles existing in its culture that promotes this detachment.

All procedures performed in studies involving human participants were in accordance with the ethical standards of the institutional and national research committee and with the 1964 Helsinki declaration and its later amendments or comparable ethical standards

\section{Informed consent}

Informed consent was obtained from all individual participants included in the study.

\section{Availability of data and material:}

The datasets generated and/or analyzed during the current study are not publicly available due to the fact that personal information is shared by the participants in their interviews and participants may be identified from details they share in their interviews, but are available from the corresponding author on reasonable request.

\section{Funding}

Research Program for the Single Health System PPSUS/TO FAPT-TO/ SESAU-TO/MS-DECIT / CNPq (Edital $n^{\circ}$ 01/2014).

Foundation for Research Support of the State of São Paulo in the Fomento modality Regular Program FAPESP (Process no 2015 / 02549-5). 
1. Silva VG. Religion and black cultural identity. Roman Catholics, AfroBrazilians and Neopentecostalism. Vibrant Virtual Braz Anthr. 2014;11(2):210-46. DOI: https://dx.doi.org/10.1590/S1809-43412014000200008

2. Eugenio BG, Lima KD. The construction of identity in the remaining community quilombola of Tucum-BA. Poiésis Rev Prog Pós Grad Educ. 2014;8(13):203-22.

3. Silva JAN. Sanitary and health conditions in Caiana dos Crioulos, a Quilombo community in the State of Paraíba. Saúde Soc. 2007;16(2):111-24. DOI: http://dx.doi.org/10.1590/S0104-12902007000200011

4. Bezerra VM, Andrade ACS, César CC, Caiaffa WT. Quilombo communities in Vitória da Conquista, Bahia state, Brazil: Hypertension and associated factors Cad Saúde Pública. 2013;29(9):1889-902. DOI: http://dx.doi.org/10.1590/0102-311X00164912

5. Gomes KO, Reis EA, Guimarães MDC, Cherchiglia ML. Use of health services by quilombo communities in southwest Bahia State, Brazil. Cad Saúde Pública. 2013;29(9):1829-42. DOI: http://dx.doi.org/10.1590/0102-311X00151412

6. Brousse C, Boisaubert B. Quality of life and scales measuring. Revue Med Interne. 2007;28(7):458-62. DOI: http://dx.doi.org/10.1016/j.revmed.2007.02.010

7. Campos MO, Rodrigues Neto JF. Qualidade de vida: um instrumento para promoção de saúde. Rev Baiana Saúde Pública. 2008;32(2):232-40.

8. Hanmer J, Feeny D, Fischhoff B, Hays RD, Hess R, Pilkonis PA, et al. The PROMIS of QALYs. Health Quality Life Outcomes. 2015;13:122. DOI: https://dx.doi.org/10.1186/s12955-015-0321-6

9. Teixeira, R. F., \& Barbosa, L. (2016). Comunidade Quilombola Barra da Aroeira (TO): abordagem fenomenológica das práticas ecológicas. Redes. 2016;21(2):63-86. DOI: http://dx.doi.org/10.17058/redes.v21i2.4757

10. Assumpção Jr FB, Kuczynski E, Sprovieri M, Aranha E. Quality of life evaluation scale (AUQEI): validity and reliability of a quality of life scale for children from 4 to 12 years-old. Rev Neuro-Psiquiatr. 2000;58(1):119-27. DOI: http://dx.doi.org/10.1590/S0004-282X2000000100018

11. Souza JGS, Pamponet MA, Souza TCS, Pereira AR, Souza AGS, Martins AMEBL. Tools used for evaluation of Brazilian children's quality of life. Rev Paul Pediatr. 2014;32(2):272-8. DOI: http://dx.doi.org/10.1590/0103-0582201432214313

12. Oliveira SKM, Pereira MM, Guimarães ALS, Caldeira AP. Self-perceived health among 'quilombolas' in northern Minas Gerais, Brazil. Ciênc Saude Coletiva. 2015; 20(9):2879-90. DOI: https://dx.doi.org/10.1590/1413-81232015209.20342014

13. Pereira RMP, Batista MA, Meira AS, Oliveira MP, Kusumota L. Quality of life of elderly patients with chronic kidney disease under conservative management. Rev Bras Enferm. 2017;70(4):887-95. DOI: http://dx.doi.org/10.1590/0034-7167-2017-0103

14. Fleck MPA, Louzada S, Xavier M, Chachamovich E, Vieira G, Santos L, et al. Application of the Portuguese version of the abbreviated instrument of quality life WHOQOL-bref. Rev Saúde Pública. 2000;34(2):178-83. DOI: http://dx.doi.org/10.1590/S0034-89102000000200012

15. Pedroso B, Picinin CT, Cantorani JRH, Gutierrez GL. Inferências da Organização Mundial da Saúde na promoção da qualidade de vida: uma explanação contemporânea dos instrumentos WHOQOL. Rev Bras Qualid Vida. 2013;5(4):19-25. DOI: http://dx.doi.org/10.3895/S2175-08582013000400003

16. Almeida-Brasil CC, Silveira MR, Silva KR, Lima MG, Faria CDCM, Cardoso CL, et al. Qualidade de vida e características associadas: aplicação do WHOQOL-BREF no contexto da Atenção Primária à Saúde. Ciênc Saúde Coletiva. 2017;22(5):1705-16. DOI: http://dx.doi.org/10.1590/1413-81232017225.20362015

17. Araújo AF, Souza MEA, Menezes CA. Quality of life and socio-economical aspects of diabetics type 1. Arq Bras Endocrinol Metab. 2008;52(7):1124-30. DOI: http://dx.doi.org/10.1590/S0004-27302008000700008

18. Castro MG, Oliveira MS, Moraes, JFD, Miguel AC, Araujo RB. Quality of life and severity of tobacco dependence. Rev Psiquiatr Clín. 2007;34(2):61-7. DOI: http://dx.doi.org/10.1590/S0101-60832007000200001

19. Gordia AP, Quadros TMB, Vilela Júnior GB, Souza EA, Cabral C, Morais TB, et al. Comparação da qualidade de vida de mulheres idosas praticantes e não praticantes de exercício físico. Rev Digital. 2007;11(106).

20. Neves ETB, Perazzo MF, Gomes, MC, Martins CC, Paiva SM, Granville Garcia AF. Perception of 
parents and self-reports of children regarding the impact of traumatic dental injury on quality of life. Dent Traumatol. 2017;33(6):444-50. DOI: http://dx.doi.org/10.1111/edt.12366

21. Andrade JMO, Rios LR, Teixeira LS, Vieira FS, Mendes DC, Vieira MA, et al. Influence of socioeconomic factors on the quality of life of elderly hypertensive individuals. Ciênc Saúde Coletiva. 2014;19(8):34973504. DOI: http://dx.doi.org/10.1590/1413-81232014198.19952013

22. Nishijima T, Martins LAR. (2010). Preservação ambiental e qualidade de vida em comunidades Quilombolas. Rev Eletr Gestão Educ Tecnol Amb. 2010;1(1):59-69.

\section{Resumo}

Introdução: Os traços de iniquidade relacionados à cor da pele ainda são observados na população brasileira, deixando evidente os prejuízos na Qualidade de Vida e cuidados da saúde da população negra.

Objetivo: Descrever a qualidade de vida dos quilombolas residentes na comunidade Barra do Aroeira no município de Santa Tereza, Tocantins, Brasil.

Método: Estudo descritivo de caráter transversal, realizado entre os meses de outubro de 2015 e setembro de 2016 na comunidade quilombola Barra do Aroeira, localizada a 12 quilômetros da área urbana do Município de Santa Teresa e a 96 quilômetros de Palmas, capital do estado de Tocantins. Foi aplicado um instrumento para a avaliação da qualidade de vida das crianças, utilizando o questionário Autoquestionnaire Qualité de Vie Enfant Imagé (Auqei), o qual possui 26 itens e uma escala composta por quatro fatores: Autonomia, Lazer, Função e Família que abrangem 18 itens, os de números 6 , $7,9,12,14,20,22$ e 26 não estão incluídas nos fatores citados por não pertencerem a um domínio específico, com isso sua análise é de forma isolada. Para avaliação da qualidade de vida em adultos foi utilizado o World Health Organization Quality of Life (WHOQOL-bref) instrumento que possui 26 assertivas, divididas em quatro domínios: físico, psicológico, relações sociais e meio ambiente, mais 2 assertivas gerais de qualidade de vida. A análise descritiva dos dados qualitativos foi realizada por frequência absoluta e frequência relativa. Para as variáveis quantitativas, utilizou-se, média, desvio padrão, mínimo e máximo. O programa utilizado foi o Stata versão 11.0.

Resultados: Em relação a qualidade de vida das crianças segundo o sexo, as meninas apresentaram média de 11,0 no fator Função, no fator Família, Lazer e Autonomia, se apresentou com média de 12,3, 8,2 e 4,8, respectivamente. Para os meninos o fator Função teve média de 11,0, o fator Família de 12,0, e os fatores Lazer e Autonomia de 7,6 e 5,6, nessa sequência. Entre os adultos os homens apresentaram menor valor no domínio Físico com média de 13,7, as mulheres tiveram menores médias nos domínios Físico e Meio ambiente, com valores iguais a 13,8. Nos escores gerais o sexo masculino obteve maior valor quando comparado ao sexo feminino, 14,0 e 13,6, respectivamente.

Conclusão: $O$ estudo demonstrou que entre as crianças o fator Familiar apresentou maiores valores médios, seguido dos fatores Função, Lazer e Autonomia, respectivamente. Ao estudar os adultos, o domínio com melhor escore foi o de Relações sociais, por outro lado, o domínio Físico apresentou o pior escore para homens e mulheres. Contudo, investigações realizadas referentes à qualidade de vida em quilombolas representam um número ainda baixo, dificultando a compreensão das possibilidades de melhoria da qualidade de vida nessa população.

Palavras-chave: qualidade de vida, populações vulneráveis.

${ }^{0}$ The authors (2018), this article is distributed under the terms of the Creative Commons Attribution 4.0 International License (http://creativecommons.org/licenses/by/4.0/), which permits unrestricted use, distribution, and reproduction in any medium, provided you give appropriate credit to the original author(s) and the source, provide a link to the Creative Commons license, and indicate if changes were made. The Creative Commons Public Domain Dedication waiver (http://creativecommons.org/publicdomain/zero/1.0/) applies to the data made available in this article, unless otherwise stated. 